\title{
Service design touch point failure model and effect analysis based on the triangular fuzzy number evaluation method
}

\author{
Weiwei Wang ${ }^{1} \cdot$ Jingling Song $^{1}$ (D) Jian Chen ${ }^{1} \cdot$ Ting Wei $^{1} \cdot$ Jin Ning $^{1}$
}

Received: 18 March 2021 / Accepted: 29 October 2021 / Published online: 5 January 2022

(c) The Author(s), under exclusive licence to Springer-Verlag France SAS, part of Springer Nature 2022

\begin{abstract}
How to improve employees' satisfaction in the remote office mode while working together has become a challenge for enterprises to deal with the new office management mode. The concept of service design touch point is introduced into the remote office management system to improve employees' office experience and help enterprises complete the remote office service design. From the perspective of virtuous circle, the cost of failure analysis and preventive measures for service design touch point in the process of service design is lower than that of dealing with failure after service failure. Therefore, this paper made a risk assessment on the failure mode of service design touch point loss analysis method based on the triangular fuzzy number evaluation method. In the failure risk assessment, the fuzzy failure mode and effect analysis theory and the failure mode of service design touch point are analyzed first, and the expert scoring method is used to evaluate and determine the fuzzy level of severity, occurrence and detection of each failure mode; Then, aiming at the ability difference of different experts in evaluating different objects, the expert importance matrix, which is based on attribute difference, is determined; On this basis, the risk priority value of each failure mode is analyzed and determined by fuzzy calculation method. The risk evaluation ranking results of touch point failure modes are obtained according to the risk priority value. Finally, taking the failure analysis of Y company's remote collaborative office service as an example, the feasibility of the method is verified by the case of protection during COVID-19.
\end{abstract}

Keywords Service design touch point · Fuzzy failure mode · Failure model and effect - Triangular fuzzy number

\section{Introduction}

With the rapid development of Internet and information technology [1], people pay more and more attention to the flexible choice of workplace and the extent to which these choices help employees integrate work and personal life [2]. The demand for online remote collaborative office is increasing

Jingling Song

SongJingling1006@163.com

Weiwei Wang

wangweiwei@sust.edu.cn

Jian Chen

ureycj@163.com

Ting Wei

wt@joya.cn

Jin Ning

1158174499@qq.com

1 College of Art and Design, Shaanxi University of Science and Technology, Weiyang District, Xi' an 710021, Shaanxi, China rapidly [3]. With the rapid transformation from traditional office mode to remote office mode, enterprises are facing the severe test of unknown and fluctuation in employee efficiency management, and employees' workflow and emotional state have changed significantly. Therefore, how to deal with the new office management mode has become a challenge for enterprises.

From the perspective of service design, enterprises need to provide high-quality services to improve employees' experience in remote office mode, realize value creation and improve office efficiency [4]. Although an enterprise collaborative office system can improve enterprise office efficiency, simplify office processes and reduce human resource costs for enterprises [5], however, in the final analysis, the focus of the collaborative mobile office is the flow of information, and ultimately the interaction between employees [6]. The carrier of the interaction process is the service design touch point of service design, which dynamically exists around users and forms an iterative closed loop. Service design touch point is a critical moment affecting user experience and an 
important indicator to measure user satisfaction with service. The number of service design touch point is huge and covers a wide range. In the service process, the failure of service design touch point will break the balance between service providers and users, bring bad experiences to customers, and is an important factor affecting service quality.

From the perspective of virtuous circle, the cost of failure analysis and preventive measures for service design touch point in the process of service design is lower than that of dealing with failure after service failure. Therefore, this paper introduces the concept of service design touch point failure analysis into the remote office management system, based on the fuzzy failure model and effect (FMEA) method, uses fuzzy language to judge the severity, occurrence and detection measure of each risk mode, and prioritizes the risk of service design touch point failure. In order to avoid human judgment error, more objectively evaluate the failure risk of service design service design touch point, and provide basis for service design touch point failure risk management.

This paper is organized as follows. The second section introduces the related work of the determination of the service design touch point, the application of FMEA and the application of application of Fuzzy set in the service process. Section 3 introduces the analysis and calculation process of the proposed method. Section 4 provides a case study to illustrate the detailed procedures of the proposed methodology. Finally, the significance and limitations of the proposed method are discussed in the last section.

\section{Literature review}

The failure of service design touch point directly affects the quality of service [4]. There are many methods of service design touch point failure analysis, which can be divided into subjective method, objective method and combination method. Subjective methods are judged by service design experts according to experience, such as analytic hierarchy process (AHP) [5], service quality (SERVQUAL) [6], etc. Due to the uncertainty of human behavior in the process of failure analysis of service design touch point, most previous studies used subjective methods to analyze and determine the failure of service design touch point. In order to comprehensively consider the direction of service design touch point failure, this paper uses the subjective and objective method to analyze the failure of service design touch point, and then uses triangular fuzzy number evaluation to determine the direction of failure risk more objectively.

\subsection{Application of failure model and effect analysis}

Failure model and effect analysis (FMEA) method is a basic method to analyze the causal relationship of failure [7]. It takes failure as the object of risk assessment and uses flow chart or causal relationship chart to analyze [8]. It can find potential failure and serious effect of failure in production or design in advance, and then use corresponding measures to solve the risk, avoid the occurrence of risk or reduce the consequences of failure [9]. In [10], the authors used FMEA method to evaluate the challenges faced by enterprises in purchasing goods, and puts forward that proper purchasing plan, implementation of cost management system and strengthening of file system are the main measures to improve the purchasing process. Based on the FMEA analysis, studied and simulated the insights from System-level Software Failure Mode and Effects Analysis method best practices of space systems, and proposes a framework to help novice engineers identify high effect failure modes. In [11], authors combined service blueprint with failure mode and effect analysis to help service designers design a fault-free service system. In the proposed approach, the blueprint [12] of the service system should be developed first to identify the potential failure points and failure modes of the front and back office service activities [13]. On this basis, the FMEA tool is used to prioritize the key potential failure modes of the service system, and necessary measures are taken to ensure the quality of service [13].

Failure mode and effect analysis (is a tool to share diagnostic knowledge between engineering and field services, and a possible means to implement service design [14]. Early in the design process, designers are assisted in developing diagnostic service tools and designs, rather than post production activities. Based on the traditional FMEA, this study gives different weights to the severity $(\mathrm{S})$, occurrence $(\mathrm{O})$ and detection (D) of risk priority number, which makes the difference factors of the three indicators appear, improves the accuracy of risk priority number, and fully considers the subjective and objective factors of service touch point design.

\subsection{Application of triangular fuzzy number}

Triangular fuzzy number is an important fuzzy number, which can solve the problems in uncertain environment [15]. It is widely used in quality management and risk management [16]. In the study of fuzzy set theory based on triangular fuzzy numbers, in [17], the authors studied many forms of fuzzy numbers and used them to solve relevant decisionmaking problems. In [18], the authors constructed a new triangular preference relationship based on triangular fuzzy numbers, measured the opinions of decision experts through consensus degree, and proposed Chinese intelligence triangular weighted aggregation operator to solve the problem of fuzzy group decision-making. In [19], the authors proposed a correlation operator using triangular fuzzy information and applied it to the fuzzy multi-attribute decision-making prob- 
lem to solve the problem of online supply chain financial credit risk assessment.

Different applications of triangular fuzzy numbers provide a variety of ideas for this paper. Triangular fuzzy numbers can effectively represent the information that is difficult to be described by accurate numerical values, and can also be flexibly transformed with other fuzzy numbers to solve the related problems in many fields [20]. Therefore, this paper proposes a service design touch point fault risk analysis method based on triangular fuzzy number evaluation, constructs a fuzzy set for each evaluation factor, helps experts relatively accurately describe the failure risk, and considers the failure factors more objectively and comprehensively in the analysis process, according to the triangular fuzzy number theory, a more accurate risk assessment value is given to guide the service design touch point design.

\section{Methodology}

The method in this paper is mainly different from the traditional FEMA method. Fuzzy language is used to judge the severity, occurrence and detection measure of each risk mode, and the risk of service design touch point failure is prioritized. As shown in Fig. 1, the method mainly has three phases.

Phase 1 Identify service design touch point.

First, determine the service process, analyze and draw the current service blueprint [21]. For the analysis stakeholders based on the service process, and secondly, identify and determine the touch points. Finally, code the service design touch points.

Phase 2 Building a model of fuzzy set for failure.

There are two main steps in this phase. The main content of this research is to construct a fuzzy set for the failure factors of user behavior service design touch point in the failure analysis process. Determining the FMEA evaluation team is to establish an FMEA expert experience database, deterministic fuzzy set, and determine the failure mode of user behavior service design touch point [22]. Combined with fuzzy set of failure factors, comprehensive evaluation is carried out and the fuzzy risk priority number (FRPN) of each service design touch point is comprehensively calculated and output.

Phase 3 Case verification program evaluation.

Case verification was conducted through the failure of service design touch point during the service process of $Y$ company's remote collaborative office service during the epidemics.

\subsection{To acquire service design touch point}

According to user-centric and efficient management of stakeholder analysis point of contact, draw the blueprint stage enterprise remote office services [23]. Through the service blueprint, assist enterprises to sort out and dismantle complex service systems, and clarify the service responsibilities of each department member [24]. Drawing a service blueprint can clearly present the user's various service design touch point. The analysis process is shown in Fig. 2.

\subsection{Fuzzy failure mode effect analysis for service design touch point failure analysis}

In the actual analysis process of FMEA, there are many fuzzy languages, such as "should", "seemingly", "very prominent", "small", etc. Fuzzy language can express these fuzzy languages with corresponding fuzzy mathematics. In this process, the fuzziness of people's thinking and expression can be fully expressed and the evaluation is more objective.

\subsubsection{Operation of triangular fuzzy numbers}

A fuzzy number is a fuzzy subset of a set of real numbers. In practice, we often use triangular fuzzy numbers to solve uncertain problems in the field of risk management and quality management. In the problem of failure mode risk assessment, some evaluation indicators are difficult to quantify. They are mainly qualitative description and only use fuzzy words such as "very", "possible" and "general" or a certain language evaluation level. However, this description can better reflect the accurate understanding of experts on the problem and is also in line with objective reality and human expression.

A triangular fuzzy number (TFN) $\tilde{A}$ can be denoted as $\tilde{A}=(L, M, U)$

$\mu_{\tilde{A}(x)} \begin{cases}\frac{x-L}{M-L} & L \leq x \leq M \\ \frac{U-x}{U-M} & M \leq x \leq U \\ 0 & \text { Otherwise }\end{cases}$

where $L \leq M \leq U$ and $L \geq 0$, which are illustrated in Fig. 3 . The membership function, $u_{\tilde{A}(x)}$, is defined as where $x$ takes its values on the real line. A larger $u_{\tilde{A}(x)}$ means a stronger degree of belongingness for $x$ in $X$. Triangular fuzzy numbers appear as useful means of quantifying the uncertainty in decision making due to their intuitive appeal and computationally efficient representation.

In the actual calculation of triangular fuzzy number, there are the following calculation rules: 


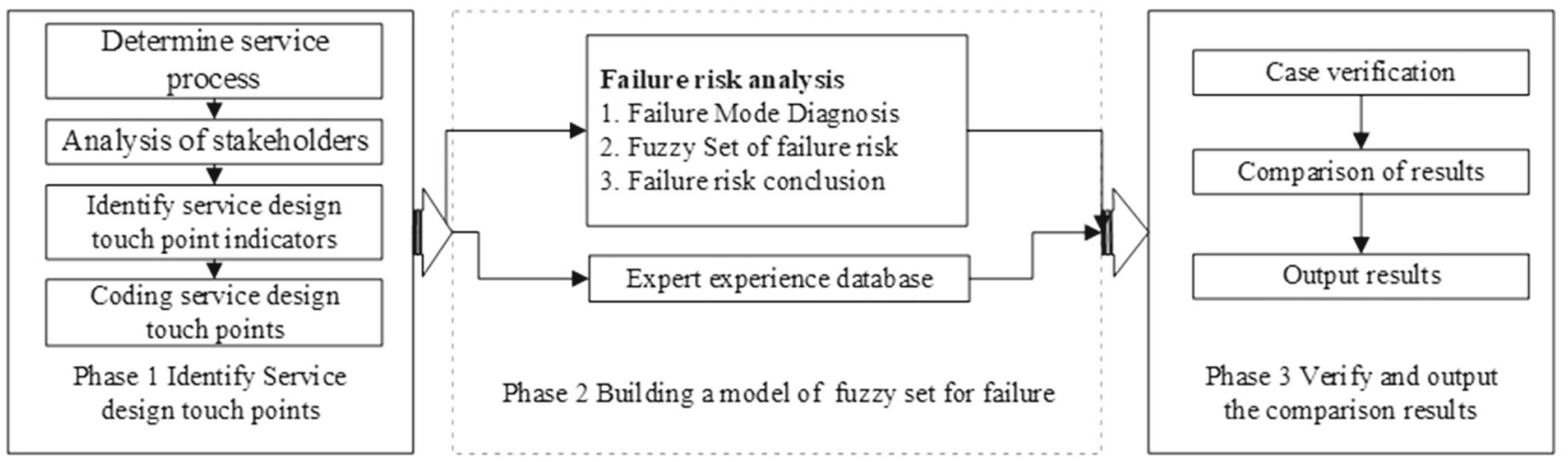

Fig. 1 The process of fuzzy FMEA method for service touch point failure

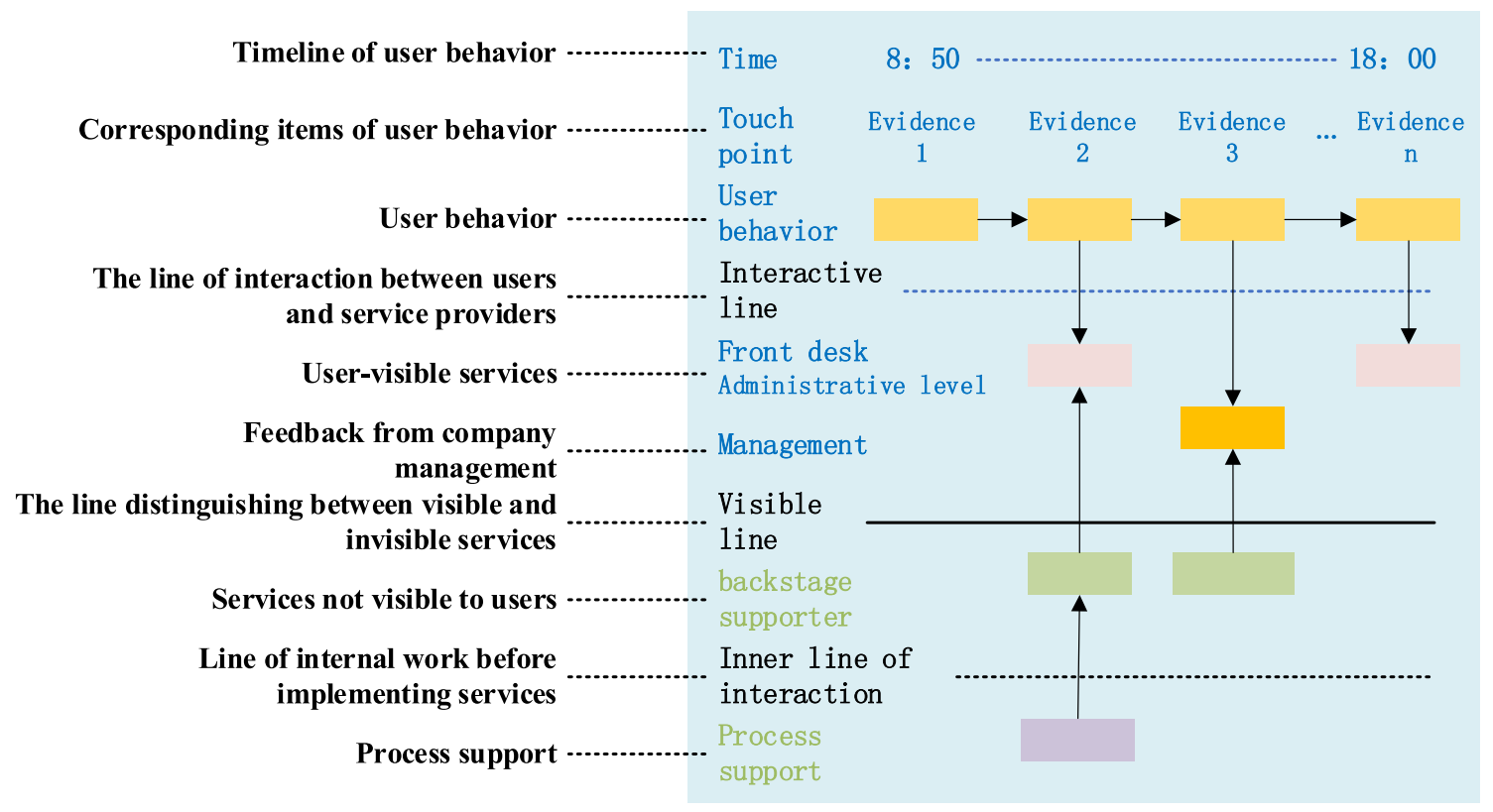

Fig. 2 Service process analysis to determine the service design touch point process

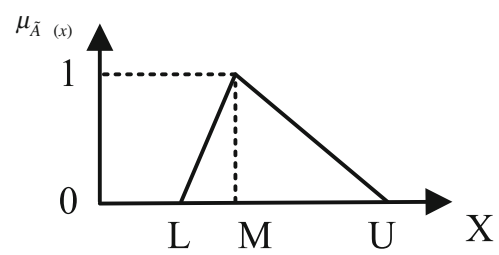

Fig. 3 Illustration of a triangular fuzzy number $\tilde{A}$

1. Addition of triangular fuzzy number:

$$
\begin{aligned}
\tilde{A}_{1}+\tilde{A}_{2} & =\left(L_{1}, M_{1}, U_{1}\right)+\left(L_{2}, M_{2}, U_{2}\right) \\
& =\left(L_{1}+L_{2}, M_{1}+M_{2}, U_{1}+U_{2}\right)
\end{aligned}
$$

2. Multiplication of triangular fuzzy number:

$$
\begin{aligned}
\tilde{A} * \tilde{A} & =\left(L_{1}, M_{1}, U_{1}\right) *\left(L_{2}, M_{2}, U_{2}\right) \\
& =\left(L_{1} L_{2}, M_{1} M_{2}, U_{1} U_{2}\right)
\end{aligned}
$$

3. Number multiplication of triangular fuzzy number:

$$
\lambda \tilde{A}=\lambda(L, M, U)=(\lambda L, \lambda M, \lambda U) \lambda>0, \quad \lambda \in R
$$

4. Reciprocal operation of triangular fuzzy number:

$$
\tilde{A}=(L, M, U)^{-1}=\left(\frac{1}{L}, \frac{1}{M}, \frac{1}{U}\right)
$$




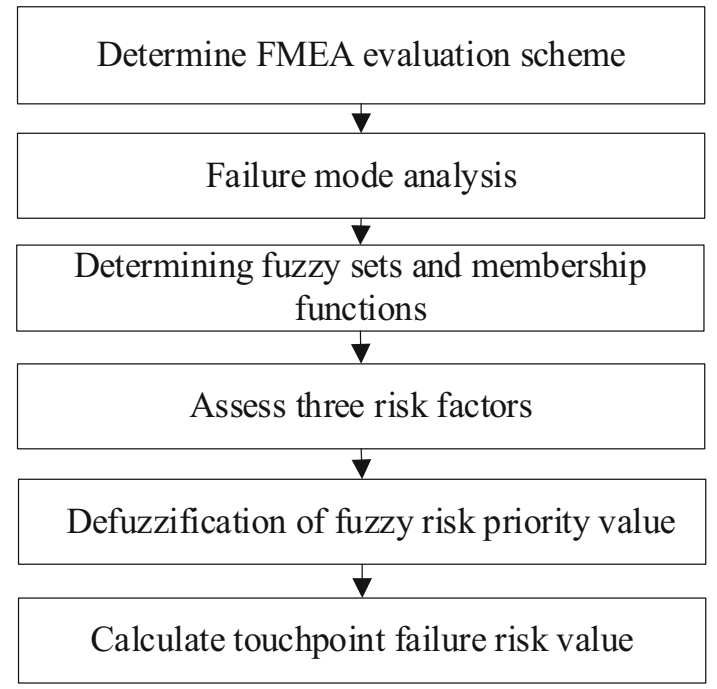

Fig. 4 Process model of failure analysis fuzzy failure mode effect analysis method

\subsubsection{Defuzzification of triangular fuzzy numbers}

For fuzzy multi criteria decision making problem, defuzzification is a very important step. There are many different methods for defuzzification, but the most commonly used is the center of gravity method. Its idea is to take the center of gravity of the area surrounded by the membership function curve and abscissa as the final output value of fuzzy reasoning [25], as shown in formula (6). The value of deblurring represented by $x(\tilde{A})$.

$x(\tilde{A})=\frac{\int_{L}^{U} x \mu_{\tilde{A}}(x) \mathrm{d} x}{\int_{L}^{U} \mu_{\tilde{A}}(x) \mathrm{d} x}$

where $x(\tilde{A}) x$ represents the value of defuzzification.

\subsubsection{Fuzzy failure mode effect analysis process of service design touch point}

Failure mode effect analysis is an effective method to reduce risk and improve reliability [26]. After coding and determining the touch point, the whole process systematically analyzes the possible failure modes in the process, finds out the failure causes, and evaluates the consequences and severity of each failure mode and the existing control measures. Fuzzy language is used to judge the severity, occurrence and detection of each risk mode, and the risk of service design touch point failure is prioritized. In order to objectively evaluate the service design touch point failure risk [27], the process model of the method proposed in this paper is shown in Fig. 4.
FMEA is used to analyze the service design touch point failure in the existing enterprise collaborative office service system, which is mainly divided into six steps:

Step 1: To form an FMEA evaluation team.

Remoting collaborative office is a work that requires teamwork and complex processes, involving the collaboration of multiple departments. The component FMEA failure analysis team gathers experts in several business-related fields, and uses their rich historical experience and professional judgment to form an expert experience database [28].

Step 2: Failure analysis of service touch point indicators.

FMEA team members formulate an FMEA evaluation plan through negotiation to determine the fuzzy set [29] and use brainstorming to analyze the possible failure modes of each service design touch point during the service process; trace the potential cause of the service design touch point failure; predict the effect and consequences (failure effects and consequences), summarize and complete the initial service design touch point failure mode analysis.

Step 3: Deterministic triangular fuzzy numbers.

The traditional FEMA method measures and scores the severity (S), occurrence $(\mathrm{O})$ and detection $(\mathrm{D})$ of three failure analysis modes from 1 to 10 , and each risk factor corresponds to a specific degree grade and score [25]. In this study, fuzzy language was used to evaluate the three risk factors of severity $(\mathrm{S})$, occurrence $(\mathrm{O})$ and detection $(\mathrm{D})$, which were processed into triangular fuzzy numbers instead of accurate values, and the fuzzy grade and triangular fuzzy number were defined.

The trigonometric fuzzy language term set is established by referring to literature [30], and each variable is evaluated with 5 evaluation language terms. The estimated value of each evaluation index is $[0,10]$, with a total of 11 grades corresponding to 5 evaluation language terms. The trigonometric fuzzy number of evaluation language terms is expressed as $v=(L, M, U)$, Where $L \leq M \leq U$ and $L \geq 0$. The meanings of fuzzy evaluation language terms corresponding to each evaluation term are shown in Table 1.

In Table 1, the evaluation value of risk factor evaluation index of failure mode by evaluation experts is expressed by five hierarchical language variables [31], namely $v=$ [very high $(\mathrm{VH})$, high $(\mathrm{H})$, medium $(\mathrm{M})$, low $(\mathrm{L})$, very low $(\mathrm{R})]=$ $[(8.5,10,10),(6,7.5,9),(2.5,4.5,6.5),(0,1.5,3)(0,0,1)]$. If the evaluation expert considers that a failure mode does not conform to a risk factor evaluation index, the evaluation is "very low", that is, the corresponding triangular fuzzy number can be denoted as $v=(0,0,1)$; If the evaluation expert thinks that a failure mode fully conforms to the evaluation 
Table 1 Rating levels of failure risk in different directions

\begin{tabular}{|c|c|c|c|c|}
\hline Language terms & Severity (S) & Occurrence $(\mathrm{O})$ & Detectability (D) & $\begin{array}{l}\text { Triangular fuzzy } \\
\text { number }\end{array}$ \\
\hline VH & Very low severity & $\begin{array}{l}\text { Very high } \\
\text { (continuous } \\
\text { failure) }\end{array}$ & $\begin{array}{l}\text { Almost impossible } \\
\text { to detect }\end{array}$ & $(8.5,10,10)$ \\
\hline $\mathrm{H}$ & Low severity & $\begin{array}{l}\text { High (recurring } \\
\text { failure) }\end{array}$ & $\begin{array}{l}\text { Low probability of } \\
\text { detection }\end{array}$ & $(6,7.5,9)$ \\
\hline M & Moderate severity & $\begin{array}{l}\text { Moderate } \\
\text { (occasional } \\
\text { failure) }\end{array}$ & $\begin{array}{l}\text { Medium probability } \\
\text { of detection }\end{array}$ & $(2.5,4.5,6.5)$ \\
\hline $\mathrm{L}$ & High severity & $\begin{array}{l}\text { Low (relatively rare } \\
\text { failures) }\end{array}$ & $\begin{array}{l}\text { High probability of } \\
\text { detection }\end{array}$ & $(0,1.5,3)$ \\
\hline $\mathrm{R}$ & Very high severity & $\begin{array}{l}\text { Very low (failure is } \\
\text { unlikely to occur) }\end{array}$ & $\begin{array}{l}\text { Very likely to be } \\
\text { detected }\end{array}$ & $(0,0,1)$ \\
\hline
\end{tabular}

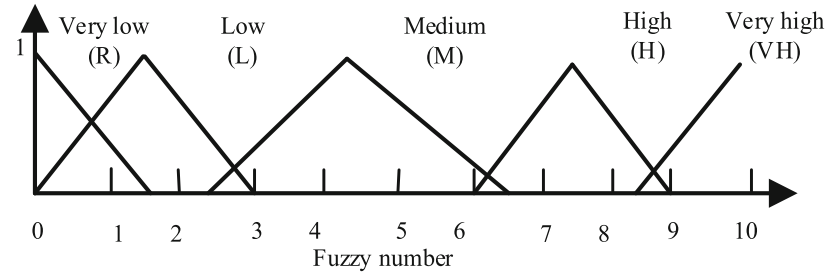

Fig. 5 Triangular fuzzy number membership function curves of five language variables

index of a risk factor, the evaluation is "very high", that is, the triangular fuzzy number can be denoted as $v=(8.5,10$, 10). Each evaluation term corresponds to a triangular fuzzy number, and their membership function curves are shown in Fig. 5.

Step 4: Assessment for three risk factors.

Before the evaluation, we assumed that there are $n$ risk modes marked $F_{i},(i=1,2, \ldots n), m$ experts grade and evaluate the failure modes marked $E_{j},(j=1,2, \ldots m)$, let $\tilde{A}_{i j}^{S}=\tilde{A}_{i j \mathrm{~L}}^{S}, \tilde{A}_{i j \mathrm{M}}^{S}, \tilde{A}_{i j \mathrm{U}}^{S}, \tilde{A}_{i j}^{\mathrm{O}}=\tilde{A}_{i j \mathrm{~L}}^{\mathrm{O}}, \tilde{A}_{i j \mathrm{M}}^{\mathrm{O}}, \tilde{A}_{i j \mathrm{U}}^{\mathrm{O}}$ and $\tilde{A}_{i j}^{\mathrm{D}}=\tilde{A}_{i j \mathrm{~L}}^{\mathrm{D}}, \tilde{A}_{i j \mathrm{M}}^{\mathrm{D}}, \tilde{A}_{i j \mathrm{U}}^{\mathrm{D}}$ respectively represent the triangular fuzzy numbers corresponding to the severity (S), occurrence (O) and detection (D) of the $i$ th failure mode of the $j$ th expert [32]. The severity (S), occurrence (O) and detection (D) correspond to the triangular fuzzy numbers of the $i$ th risk mode, as shown in formulas (7), (8) and (9).

$$
\begin{gathered}
\tilde{A}_{i}^{S}=\sum_{j=1}^{m} a_{j} \tilde{A}_{i j}^{S} \\
\tilde{A}_{i}^{O}=\sum_{j=1}^{m} a_{j} \tilde{A}_{i j}^{O}
\end{gathered}
$$

$$
\tilde{A}_{i}^{D}=\sum_{j=1}^{m} a_{j} \tilde{A}_{i j}^{D}
$$

where $\tilde{A}_{i}^{S}, \tilde{A}_{i}^{O}$ and $\tilde{A}_{i}^{D}$ respectively represent the triangular fuzzy numbers of severity (S), occurrence $(\mathrm{O})$ and detection (D) of the $i$ th risk mode [33]. Since the experience of each expert is different, we define $a_{j}(j=1,2 \ldots, m)$ represents the weight of $m$ experts, and $\sum_{j=1}^{m} a_{j}=1, a_{j} \in(0,1)$ [34].

\section{Step 5: Defuzzification of fuzzy risk priority value.}

For ranking purpose, the FRPNs are defuzzified using centroid defuzzification method, in which the defuzzification process of a triangular fuzzy number $\tilde{A}=(\mathrm{L}, \mathrm{M}, \mathrm{U})$ can be obtained by formula (6) [35]. Therefore, the defuzzification process for the methods $\mathrm{S}, \mathrm{O}$ and $\mathrm{D}$ respectively can be rewritten into formulas (10), (11) and (12) in this method.

$$
\begin{aligned}
& \mathrm{DS}_{\mathrm{i}}=\frac{1}{3}\left(A_{i \mathrm{~L}}^{S}+A_{i \mathrm{M}}^{S}+A_{i \mathrm{U}}^{S}\right) \\
& \mathrm{DO}_{\mathrm{i}}=\frac{1}{3}\left(A_{i \mathrm{~L}}^{O}+A_{i \mathrm{M}}^{O}+A_{i \mathrm{U}}^{O}\right) \\
& \mathrm{DD}_{\mathrm{i}}=\frac{1}{3}\left(A_{i \mathrm{~L}}^{D}+A_{i \mathrm{M}}^{D}+A_{i \mathrm{U}}^{D}\right)
\end{aligned}
$$

$\mathrm{DS}_{i}, \mathrm{DO}_{i}$ and $\mathrm{DD}_{i}$ respectively represent the severity, occurrence and detection measure values obtained after fuzzy theory processing in the $i$ th risk model.

Step 6: Calculation of fuzzy risk priority number value.

Compared with the traditional FEMA calculation of fuzzy risk priority value FRPN, this study combined the three risk factor levels assessed by experts with triangular fuzzy number, and obtained the fuzzy risk priority value FRPN through 
fuzzification and defuzzification. $\mathrm{FRPN}_{i}$ represents the failure risk priority value of the $i$ th risk mode, and the calculation process is shown in formula (13).

$\mathrm{FRPN}_{i}=\mathrm{DS}_{i} \times \mathrm{DO}_{i} \times \mathrm{DD}_{i}$

\section{Case verification study}

In the process of remote collaborative office, employee experience is an important aspect of service design touch point. In other words, employee satisfaction determines the quality of service design. In the case of complex influencing factors, according to stakeholders and efficient management point of contact analysis, the blueprint of remote office services of $\mathrm{Y}$ company during the epidemic [36] determines that the point of touch indicators and encoded. Establishing an FMEA evaluation team to negotiate and evaluating the failure risk of touch points to determine the failure risk factors are also needed. Then, aiming at the ability difference of different experts in evaluating different objects, the expert importance matrix based on attribute difference is determined. On this basis, the risk priority value of each failure mode is analyzed and determined by fuzzy calculation method.

\subsection{Y company profile}

Y company is a new innovative company based in China, focusing on design services. During the protection period of the COVID-19, the original management system was optimized and adjusted. To a certain extent, the enterprise collaborative office system improves office efficiency, simplifies office processes, and reduces human resource costs for the enterprise. However, high-efficiency office cannot be separated from the initiative of each employee [36]. In order to further improve service quality and reduce the occurrence of service errors, company $\mathrm{Y}$ intends to analyze the potential failure modes and effects of its remote office service design touch point during the epidemic period to explore the remote online office mode to meet the needs of employees in the remote office mode.

\subsection{Sort out and code service design touch point}

Through the analysis of user behavior [37] assist the company to sort out the service system in its remote office process, and clarify the work content of each department member [38]. Using the service blueprint method to clearly present the touch points of users around user behaviors is also needed. The physical evidence, user journey, front-end and back-end behavior, and process support are visualized, and the entire service interaction relationship is clearly revealed through the expansion of the time axis [36]. The blueprint for remote
Table 2 Index of touch points of Y company's online office services

\begin{tabular}{lll}
\hline Stage & Code & Touch point indicator description \\
\hline Morning & F1 & Punch in \\
& F2 & Assign tasks early \\
& F3 & Accept tasks and make plans \\
& F4 & Clear task time node \\
& F5 & At working \\
& F6 & Morning work content file output \\
& F7 & Rest at noon \\
F8 & Check in at work in the afternoon \\
& F9 & Document review \\
F10 & File output \\
F11 & Have a meeting (summary of task completion) \\
& F12 & Punch out \\
\hline
\end{tabular}

daily office services of Y company is shown in Fig. 6a. Stakeholder analysis and screening were introduced to determine the service design touch point indicators for failure analysis and coded. The coding results are shown in Table 2 .

\subsection{Service design touch point failure analysis}

The FMEA team members negotiated and analyzed and determined the possible failure modes of the 12 service design touch point indicators in the service process of $\mathrm{Y}$ company remote office, traced the potential causes of their failures, predicted the effect and consequences, summarized and completed the preliminary service design touch point failure mode analysis, and the analysis results are shown in the Table 3 shown.

\subsection{Determine fuzzy language set}

The severity of FMEA risk factors (the severity of the consequences when failure modes occur) is regarded as a fuzzy language variable, a fuzzy language term set is established, and each variable is evaluated with five evaluation language terms. The estimation of each evaluation index is taken in the $[0,10]$ area, with a total of 11 grades, corresponding to five evaluation terms, expressed as $V=$ [Very high $(\mathrm{VH})$, High (H), Medium (M), Low (L), Very low (R)].

The severity of the consequences when the failure mode occurs. When the potential failure mode leads to defects in the final employees or internal management personnel, the corresponding grading results can be identified. Finally, the experience of employees should be considered first. If both possibilities exist, the higher of the two severity values shall be adopted. The severity fuzzy set of failure severity degree is shown in Table 4. 
Table 3 Failure mode analysis of Y company's remote office service design touch point

\begin{tabular}{|c|c|c|c|}
\hline Code & Failure mode & Reason for failure & $\begin{array}{l}\text { Consequences of } \\
\text { failure }\end{array}$ \\
\hline $\mathrm{F} 1$ & $\begin{array}{l}\text { Time card page } \\
\text { stuck }\end{array}$ & Too many visitors & $\begin{array}{l}\text { The effect of } \\
\text { being late for } \\
\text { work }\end{array}$ \\
\hline $\mathrm{F} 2$ & $\begin{array}{l}\text { Too many } \\
\text { participants and } \\
\text { slow website }\end{array}$ & $\begin{array}{l}\text { Large number of } \\
\text { participants }\end{array}$ & $\begin{array}{l}\text { Some employees } \\
\text { cannot } \\
\text { participate in } \\
\text { the morning } \\
\text { meeting }\end{array}$ \\
\hline F3 & Slow plan update & $\begin{array}{l}\text { Information } \\
\text { synchronization } \\
\text { is not timely }\end{array}$ & $\begin{array}{l}\text { Some employees } \\
\text { do not know } \\
\text { their tasks }\end{array}$ \\
\hline $\mathrm{F} 4$ & $\begin{array}{l}\text { Task time node is } \\
\text { not released }\end{array}$ & Network delay & $\begin{array}{l}\text { Some employees } \\
\text { cannot arrange } \\
\text { their jobs } \\
\text { reasonably }\end{array}$ \\
\hline F5 & $\begin{array}{l}\text { Unable to } \\
\text { communicate in } \\
\text { time if there is a } \\
\text { problem }\end{array}$ & $\begin{array}{l}\text { Inability to } \\
\text { communicate } \\
\text { effectively in } \\
\text { person }\end{array}$ & $\begin{array}{l}\text { Project progress } \\
\text { is slow }\end{array}$ \\
\hline F6 & $\begin{array}{l}\text { It has been } \\
\text { submitted, but } \\
\text { the page shows } \\
\text { that it has not } \\
\text { been submitted }\end{array}$ & $\begin{array}{l}\text { Information } \\
\text { synchronization } \\
\text { is not timely }\end{array}$ & $\begin{array}{l}\text { The employee is } \\
\text { not sure } \\
\text { whether to } \\
\text { submit }\end{array}$ \\
\hline F7 & $\begin{array}{l}\text { Failed to finish } \\
\text { lunch on time }\end{array}$ & $\begin{array}{l}\text { Different personal } \\
\text { habits/emergency } \\
\text { other situations }\end{array}$ & $\begin{array}{l}\text { Late for work in } \\
\text { the afternoon / } \\
\text { unable to work } \\
\text { in the afternoon }\end{array}$ \\
\hline F8 & $\begin{array}{l}\text { Too many } \\
\text { employee visits } \\
\text { and slow } \\
\text { website speed }\end{array}$ & $\begin{array}{l}\text { Some employees } \\
\text { have poor } \\
\text { network signal }\end{array}$ & $\begin{array}{l}\text { The employees } \\
\text { are not there } \\
\text { and cannot } \\
\text { work normally }\end{array}$ \\
\hline F9 & $\begin{array}{l}\text { Review status } \\
\text { progress cannot } \\
\text { be queried }\end{array}$ & $\begin{array}{l}\text { Information } \\
\text { synchronization } \\
\text { is not timely }\end{array}$ & $\begin{array}{l}\text { The project } \\
\text { cannot proceed } \\
\text { as planned }\end{array}$ \\
\hline F10 & $\begin{array}{l}\text { Uploading time is } \\
\text { too long during } \\
\text { file output }\end{array}$ & Network delay & $\begin{array}{l}\text { Extend working } \\
\text { hours }\end{array}$ \\
\hline F11 & $\begin{array}{l}\text { Meeting } \\
\text { communication } \\
\text { is delayed in } \\
\text { time }\end{array}$ & $\begin{array}{l}\text { Communication } \\
\text { is not timely }\end{array}$ & $\begin{array}{l}\text { Overtime } \\
\text { completed }\end{array}$ \\
\hline F12 & $\begin{array}{l}\text { Forgot to check } \\
\text { in after get off } \\
\text { work }\end{array}$ & $\begin{array}{l}\text { Forgot to open the } \\
\text { collaborative } \\
\text { work system }\end{array}$ & Lost wages \\
\hline
\end{tabular}

Occurrence degree refers to the possibility of the occurrence of a specific cause. The evaluation occurrence degree (possibility of failure mode occurrence) index of FMEA risk factors is regarded as a fuzzy language variable, a fuzzy linguistic term set is established, and each variable is evaluated with five evaluation language terms. The estimation score of each evaluation index is taken in the interval of $[0,10]$, a
Table 4 Fuzzy set of failure severity degree

\begin{tabular}{|c|c|c|c|}
\hline Effect & $\begin{array}{l}\text { Evaluation } \\
\text { criteria }\end{array}$ & $\begin{array}{l}\text { Language } \\
\text { terms }\end{array}$ & $\begin{array}{l}\text { Triangular } \\
\text { fuzzy number }\end{array}$ \\
\hline Great effect & $\begin{array}{l}\text { When a } \\
\text { potential } \\
\text { failure mode } \\
\text { affects the } \\
\text { user's own } \\
\text { safety or } \\
\text { safety } \\
\text { and/or } \\
\text { involves } \\
\text { non- } \\
\text { compliance } \\
\text { with } \\
\text { government } \\
\text { regulations, } \\
\text { the severity } \\
\text { rating is } \\
\text { very high }\end{array}$ & VH & $(8.5,10,10)$ \\
\hline Greater effect & $\begin{array}{c}\text { Service not } \\
\text { available }\end{array}$ & $\mathrm{H}$ & $(6,7.5,9)$ \\
\hline $\begin{array}{l}\text { Moderate } \\
\text { effect }\end{array}$ & $\begin{array}{l}\text { The service } \\
\text { can be } \\
\text { performed } \\
\text { but the com- } \\
\text { fort/convenience } \\
\text { items cannot } \\
\text { be } \\
\text { performed, } \\
\text { and the user } \\
\text { is not } \\
\text { satisfied }\end{array}$ & M & $(2.5,4.5,6.5)$ \\
\hline Slight effect & $\begin{array}{l}\text { Physical } \\
\text { display is } \\
\text { uncomfort- } \\
\text { able. Most } \\
\text { (more than } \\
50 \% \text { ) users } \\
\text { can detect } \\
\text { defects }\end{array}$ & $\mathrm{L}$ & $(0,1.5,3)$ \\
\hline No effect & $\begin{array}{l}\text { Indiscriminate } \\
\text { influence }\end{array}$ & $\mathrm{R}$ & $(0,0,1)$ \\
\hline
\end{tabular}

total of 11 grades, corresponding to five evaluation terms, expressed as $V=[$ Very high (VH), High (H), Medium (M), Low (L), Very low (R)].

The fuzzy set of failure occurrence degree is shown in Table 5. The number of occurrence levels in FMEA is a relative level within its range, which is obtained by comparison. The occurrence degree level may not reflect the possibility of the actual failure mode. The only way to reduce the frequency is to prevent or control the failure mode through design change.

Detection degree is the rating number associated with the best detection control listed in the process control column, and is the relative level of a failure mode within its range. The detectability (probability of failure being detected) index of 
Table 5 Fuzzy set of failure occurrence degree

\begin{tabular}{|c|c|c|c|}
\hline Failure rate & $\begin{array}{l}\text { Evaluation } \\
\text { criteria }\end{array}$ & $\begin{array}{l}\text { Language } \\
\text { terms }\end{array}$ & $\begin{array}{l}\text { Triangular } \\
\text { fuzzy number }\end{array}$ \\
\hline Very high & $\begin{array}{l}\text { Very high } \\
\text { frequency } \\
(>30 \%)\end{array}$ & $\mathrm{VH}$ & $(8.5,10,10)$ \\
\hline $\begin{array}{l}\text { High } \\
\text { (frequent } \\
\text { failure) }\end{array}$ & $\begin{array}{l}\text { High } \\
\text { frequency } \\
(\leq 30 \%)\end{array}$ & $\mathrm{H}$ & $(6,7.5,9)$ \\
\hline $\begin{array}{l}\text { Moderate } \\
\text { (accidental } \\
\text { failure) }\end{array}$ & $\begin{array}{l}\text { Medium } \\
\text { frequency } \\
(\leq 20 \%)\end{array}$ & M & $(2.5,4.5,6.5)$ \\
\hline $\begin{array}{l}\text { Low } \\
\text { (relatively } \\
\text { rare failures) }\end{array}$ & $\begin{array}{l}\text { Low } \\
\text { frequency } \\
(\leq 10 \%)\end{array}$ & $\mathrm{L}$ & $(0,1.5,3)$ \\
\hline $\begin{array}{l}\text { Very low } \\
\text { (Failure is } \\
\text { unlikely to } \\
\text { occur) }\end{array}$ & $\begin{array}{l}\text { Very low } \\
\text { frequency } \\
(\leq 1 \%)\end{array}$ & $\mathrm{R}$ & $(0,0,1)$ \\
\hline
\end{tabular}

Table 6 Fuzzy set of failure detection degree

\begin{tabular}{llll}
\hline $\begin{array}{l}\text { Detectability } \\
\text { of failure }\end{array}$ & $\begin{array}{l}\text { Evaluation } \\
\text { criteria }\end{array}$ & $\begin{array}{l}\text { Language } \\
\text { terms }\end{array}$ & $\begin{array}{l}\text { Triangular } \\
\text { fuzzy number }\end{array}$ \\
\hline $\begin{array}{c}\text { Very high } \\
\text { (continuous } \\
\text { failure) }\end{array}$ & $\begin{array}{c}\text { Detection } \\
\text { method may } \\
\text { not detect }\end{array}$ & $\mathrm{VH}$ & $(8.5,10,10)$ \\
$\begin{array}{c}\text { High } \\
\text { (recurring } \\
\text { failure) }\end{array}$ & $\begin{array}{c}\text { Control has } \\
\text { very little } \\
\text { chance to } \\
\text { detect }\end{array}$ & $\mathrm{H}$ & $(6,7.5,9)$ \\
$\begin{array}{c}\text { Moderate } \\
\text { (occasional } \\
\text { failure) }\end{array}$ & $\begin{array}{c}\text { Control may } \\
\text { detect }\end{array}$ & $\mathrm{M}$ & \\
$\begin{array}{c}\text { Low } \\
\text { (relatively } \\
\text { rare failures) }\end{array}$ & $\begin{array}{c}\text { Control has } \\
\text { more } \\
\text { chances to } \\
\text { detect }\end{array}$ & $\mathrm{L}$ & $(2.5,4.5,6.5)$ \\
Very low & $\begin{array}{l}\text { Control } \\
\text { opportuni- } \\
\text { failure is }\end{array}$ & $\mathrm{R}$ & $(0,1.5,3)$ \\
unlikely to & $\begin{array}{l}\text { ties can } \\
\text { definitely be } \\
\text { detected }\end{array}$ & & $(0,0,1)$ \\
\hline
\end{tabular}

FMEA risk factors is regarded as a fuzzy language variable, a fuzzy language term set is established, and each variable is evaluated with five evaluation language terms, The estimated value of each evaluation index is taken in the $[0,10]$, a total of 11 grades, corresponding to five evaluation terms, expressed as $V=[$ Very high $(\mathrm{VH})$, $\operatorname{High}(\mathrm{H})$, Medium $(\mathrm{M})$, Low (L), Very low (R)]. The fuzzy set of failure detection degree is shown in Table 6. In order to obtain a relatively low detection degree, the process control is improved so that it can be detected effectively.

\subsection{FEMA expert group evaluates three risk factors}

There are four experts in the remote collaborative office service design touch point failure risk assessment team, including one company manager, one executive, one designer and one safety engineer. Because each expert involves different knowledge fields and specialties, each expert is given different weight values in terms of severity, occurrence and detection. The weight of experienced experts will be higher than that of others. In this case, the experience weight of validation experts is expressed as $a=(0.25,0.15,0.4,0.2)$.

In combination with Tables 1, 2 and 3, the four experts evaluated the fuzzy levels of the three factors of each failure mode, and obtained the expert scoring levels of severity, occurrence and detection. See Table 7 for details.

Combined with Tables 4, 5 and 6 and expert weight matrix, the severity, occurrence and detection in Table 7 are fuzzed. In order to obtain more accurate results, the triangular fuzzy numbers of severity, occurrence and detection are calculated according to formulas (7), (8) and (9), as shown in Table 8.

\subsection{Defuzzification of fuzzy risk priority value}

According to formula (10), formula (11) and formula (12), the risk priority value FRPN is calculated and sorted according to formula (13) from the failure mode of each service design touch point. The results are shown in Table 9. According to the fuzzy number of each expert's rating grade of the three elements of each failure mode and the different weight values given by the experts, the risk priority value of each failure mode is calculated by using the fuzzy theory method.

The ranking of risk factors of each service design touch point in Y company's remote collaborative office is

$$
\begin{aligned}
F_{5} & >F_{1}>F_{4}>F_{3}>F_{6}>F_{12}>F_{2} \\
& >F_{9}>F_{8}>F_{7}>F_{11}>F_{10} .
\end{aligned}
$$

During the redesign of service design touch point in the later stage, priority shall be given according to the ranking of failure risks. The greater the risk value, the more priority shall be given to the design, and targeted improvement measures shall be put forward according to the failure risks in different directions.

\subsection{Service design plan comparison}

The service blueprint visualizes all service design touch point, front-end work behaviors, and back-end processes. The improvement of service quality is mainly manifested in increasing the front-end and back-end processes below the interaction line. Front desk work behaviors and background programs provide good interaction for user service design touch point and make detailed correspondence 
Table 7 Fuzzy evaluation results of service touch point failure mode

\begin{tabular}{|c|c|c|c|c|c|c|c|c|c|c|c|c|}
\hline \multirow[t]{2}{*}{ Failure mode code } & \multicolumn{3}{|c|}{ Expert 1} & \multicolumn{3}{|c|}{ Expert 2} & \multicolumn{3}{|c|}{ Expert 3} & \multicolumn{3}{|c|}{ Expert 4} \\
\hline & $\mathrm{S}$ & $\mathrm{O}$ & $\mathrm{D}$ & $\mathrm{S}$ & $\mathrm{O}$ & $\mathrm{D}$ & $S$ & $\mathrm{O}$ & $\mathrm{D}$ & S & $\mathrm{O}$ & $\mathrm{D}$ \\
\hline F1 & $\mathrm{VH}$ & M & $\mathrm{H}$ & $\mathrm{H}$ & $\mathrm{H}$ & M & $\mathrm{H}$ & $\mathrm{H}$ & $\mathrm{H}$ & M & $\mathrm{H}$ & $\mathrm{H}$ \\
\hline $\mathrm{F} 2$ & $\mathrm{H}$ & $\mathrm{H}$ & $\mathrm{L}$ & $\mathrm{L}$ & M & M & $\mathrm{H}$ & $\mathrm{H}$ & $\mathrm{L}$ & VH & M & $\mathrm{H}$ \\
\hline F3 & $\mathrm{H}$ & $\mathrm{H}$ & $\mathrm{L}$ & $\mathrm{H}$ & M & M & M & $\mathrm{VH}$ & $\mathrm{H}$ & $\mathrm{H}$ & $\mathrm{H}$ & M \\
\hline $\mathrm{F} 4$ & $\mathrm{H}$ & $\mathrm{VH}$ & $\mathrm{R}$ & $\mathrm{M}$ & $\mathrm{H}$ & $\mathrm{L}$ & $\mathrm{H}$ & $\mathrm{H}$ & $\mathrm{H}$ & $\mathrm{H}$ & $\mathrm{VH}$ & M \\
\hline F5 & $\mathrm{H}$ & $\mathrm{H}$ & $\mathrm{L}$ & $\mathrm{H}$ & M & $\mathrm{H}$ & $\mathrm{VH}$ & $\mathrm{H}$ & $\mathrm{H}$ & $\mathrm{VH}$ & $\mathrm{H}$ & $\mathrm{H}$ \\
\hline F6 & $\mathrm{H}$ & $\mathrm{H}$ & $\mathrm{L}$ & $\mathrm{M}$ & M & $\mathrm{H}$ & $\mathrm{VH}$ & $\mathrm{H}$ & M & M & $\mathrm{H}$ & $\mathrm{L}$ \\
\hline F7 & M & $\mathrm{H}$ & $\mathrm{R}$ & $\mathrm{H}$ & M & $\mathrm{L}$ & $\mathrm{H}$ & $\mathrm{H}$ & M & M & $\mathrm{H}$ & M \\
\hline F8 & $\mathrm{H}$ & $\mathrm{VH}$ & $\mathrm{L}$ & $\mathrm{H}$ & $\mathrm{VH}$ & $\mathrm{H}$ & M & $\mathrm{H}$ & $\mathrm{L}$ & M & M & M \\
\hline F9 & $\mathrm{H}$ & $\mathrm{VH}$ & $\mathrm{L}$ & $\mathrm{L}$ & $\mathrm{VH}$ & $\mathrm{H}$ & M & $\mathrm{H}$ & $\mathrm{L}$ & $\mathrm{H}$ & $\mathrm{H}$ & M \\
\hline F10 & $\mathrm{H}$ & $\mathrm{L}$ & $\mathrm{L}$ & $\mathrm{H}$ & $\mathrm{L}$ & M & $\mathrm{VH}$ & M & $\mathrm{R}$ & $\mathrm{H}$ & M & $\mathrm{M}$ \\
\hline F11 & M & M & $\mathrm{R}$ & $\mathrm{M}$ & M & $\mathrm{H}$ & $\mathrm{H}$ & M & $\mathrm{R}$ & $\mathrm{H}$ & $\mathrm{H}$ & M \\
\hline $\mathrm{F} 12$ & $\mathrm{H}$ & $\mathrm{H}$ & $\mathrm{L}$ & $\mathrm{M}$ & M & $\mathrm{H}$ & $\mathrm{VH}$ & $\mathrm{H}$ & $\mathrm{H}$ & $\mathrm{L}$ & $\mathrm{R}$ & $\mathrm{L}$ \\
\hline Expert weight & 0.25 & & & 0.15 & & & 0.4 & & & 0.2 & & \\
\hline
\end{tabular}

Table 8 Triangular fuzzy number of service design touch point failure risk factors

\begin{tabular}{|c|c|c|c|c|}
\hline Code & Failure mode & Failure severity $\tilde{\boldsymbol{A}}_{\boldsymbol{i}}^{S}$ & Failure occurrence $\tilde{A}_{i}^{O}$ & Failure detection $\tilde{A}_{i}^{D}$ \\
\hline $\mathrm{F} 1$ & Time card page stuck & $5.925,7.525,8.75$ & $5.125,6.75,8.375$ & $5.475,7.05,8.625$ \\
\hline $\mathrm{F} 2$ & $\begin{array}{l}\text { Too many participants } \\
\text { and slow website }\end{array}$ & $5.6,7.1,8.3$ & $4.775,6.45,8.125$ & $1.575,3.15,4.725$ \\
\hline F3 & Slow plan update & $4.6,6.3,8$ & $6.475,8.05,9.025$ & $3.275,4.95,6.625$ \\
\hline $\mathrm{F} 4$ & $\begin{array}{l}\text { Task time node is not } \\
\text { released }\end{array}$ & $5.475,7.05,8.625$ & $7.125,8.625,9.45$ & $2.9,4.125,5.6$ \\
\hline F5 & $\begin{array}{l}\text { Unable to } \\
\text { communicate in time } \\
\text { if there is a problem }\end{array}$ & $7.5,9,9.6$ & $5.475,7.05,8.625$ & $4.5,67.5$ \\
\hline F6 & $\begin{array}{l}\text { It has been submitted, } \\
\text { but the page shows } \\
\text { that it has not been } \\
\text { submitted }\end{array}$ & $5.775,7.45,8.525$ & $5.475,7.05,8.625$ & $1.9,3.6,5.3$ \\
\hline F7 & $\begin{array}{l}\text { Failed to finish lunch } \\
\text { on time }\end{array}$ & $4.425,6.15,7.875$ & $5.475,7.05,8.625$ & $1.5,2.925,4.6$ \\
\hline F8 & $\begin{array}{l}\text { Too many employee } \\
\text { visits and slow } \\
\text { website speed }\end{array}$ & $3.9,5.7,7.5$ & $6.3,7.9,8.9$ & $1.4,3,4.6$ \\
\hline F9 & $\begin{array}{l}\text { Review status progress } \\
\text { cannot be queried }\end{array}$ & $3.7,5.4,7.1$ & $7,8.5,9.4$ & $1.4,3,4.6$ \\
\hline F10 & $\begin{array}{l}\text { Uploading time is too } \\
\text { long during file } \\
\text { output }\end{array}$ & $7,8.5,9.4$ & $1.5,3.3,5.1$ & $0.875,1.95,3.425$ \\
\hline F11 & $\begin{array}{l}\text { Meeting } \\
\text { communication is } \\
\text { delayed in time }\end{array}$ & $4.6,6.3,8$ & $3.2,5.1,7$ & $1.4,2.025,3.3$ \\
\hline F12 & $\begin{array}{l}\text { Forgot to check in after } \\
\text { get off work }\end{array}$ & $5.275,6.85,7.825$ & $4.275,5.55,7.025$ & $3.3,4.8,6.3$ \\
\hline
\end{tabular}


Table 9 Failure risk value of remote office service design touch point of $\mathrm{Y}$ company

\begin{tabular}{|c|c|c|c|c|c|c|}
\hline Code & Failure mode & $\begin{array}{l}\text { Value of } \\
\text { failure } \\
\text { severity } \mathrm{DS}_{i}\end{array}$ & $\begin{array}{l}\text { Value of } \\
\text { failure } \\
\text { occurrence } \\
\mathrm{DO}_{i}\end{array}$ & $\begin{array}{l}\text { Value of } \\
\text { failure } \\
\text { detection } \\
\mathrm{DD}_{i}\end{array}$ & $\begin{array}{l}\text { Failure risk } \\
\text { priority } \\
\text { number } \\
\text { FRPN }\end{array}$ & $\begin{array}{l}\text { Failure risk } \\
\text { ranking }\end{array}$ \\
\hline $\mathrm{F} 1$ & $\begin{array}{l}\text { Time card } \\
\text { page stuck }\end{array}$ & 7.4 & 6.75 & 7.05 & 352.148 & 2 \\
\hline $\mathrm{F} 2$ & $\begin{array}{l}\text { Too many } \\
\text { participants } \\
\text { and slow } \\
\text { website }\end{array}$ & 7 & 6.45 & 3.15 & 142.223 & 7 \\
\hline F3 & $\begin{array}{l}\text { Slow plan } \\
\text { update }\end{array}$ & 6.3 & 7.85 & 4.95 & 244.802 & 4 \\
\hline F4 & $\begin{array}{l}\text { Task time } \\
\text { node is not } \\
\text { released }\end{array}$ & 7.05 & 8.4 & 4.208333 & 249.217 & 3 \\
\hline F5 & $\begin{array}{l}\text { Unable to } \\
\text { communi- } \\
\text { cate in time } \\
\text { if there is a } \\
\text { problem }\end{array}$ & 8.7 & 7.05 & 6 & 368.01 & 1 \\
\hline F6 & $\begin{array}{l}\text { It has been } \\
\text { submitted, } \\
\text { but the } \\
\text { page shows } \\
\text { that it has } \\
\text { not been } \\
\text { submitted }\end{array}$ & 7.25 & 7.05 & 3.6 & 184.005 & 5 \\
\hline F7 & $\begin{array}{l}\text { Failed to } \\
\text { finish lunch } \\
\text { on time }\end{array}$ & 6.15 & 7.05 & 3.008333 & 130.434 & 10 \\
\hline F8 & $\begin{array}{l}\text { Too many } \\
\text { employee } \\
\text { visits and } \\
\text { slow } \\
\text { website } \\
\text { speed }\end{array}$ & 5.7 & 7.7 & 3 & 131.67 & 9 \\
\hline F9 & $\begin{array}{l}\text { Review status } \\
\text { progress } \\
\text { cannot be } \\
\text { queried }\end{array}$ & 5.4 & 8.3 & 3 & 134.46 & 8 \\
\hline F10 & $\begin{array}{l}\text { Uploading } \\
\text { time is too } \\
\text { long during } \\
\text { file output }\end{array}$ & 8.3 & 3.3 & 2.083333 & 57.0625 & 12 \\
\hline F11 & $\begin{array}{l}\text { Meeting } \\
\text { communi- } \\
\text { cation is } \\
\text { delayed in } \\
\text { time }\end{array}$ & 6.3 & 5.1 & 2.241667 & 72.0248 & 11 \\
\hline F12 & $\begin{array}{l}\text { Forgot to } \\
\text { check in } \\
\text { after get off } \\
\text { work }\end{array}$ & 6.65 & 5.616667 & 4.8 & 179.284 & 6 \\
\hline
\end{tabular}




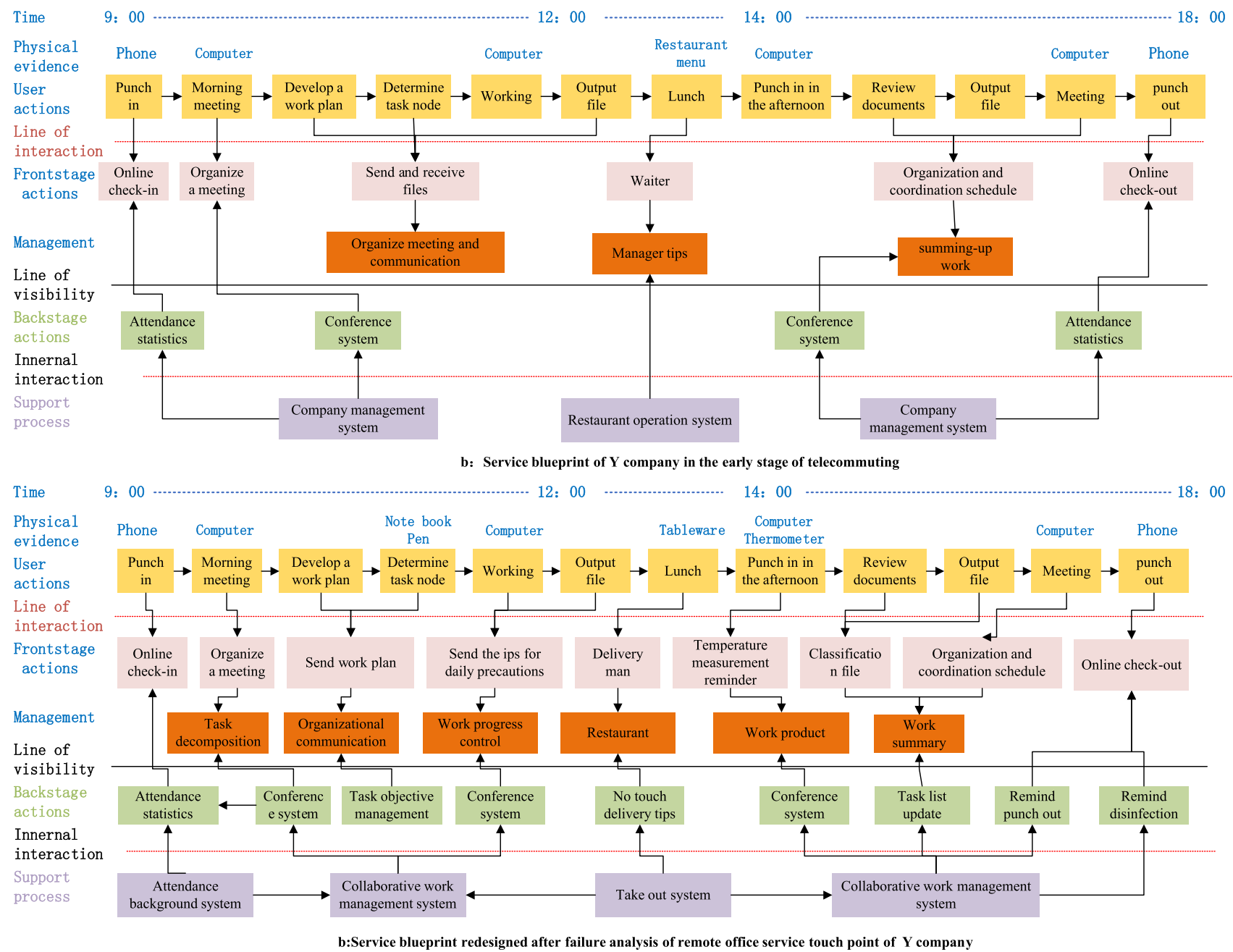

Fig. 6 Comparison of Y company's remote office service design blueprint schemes

Table 10 Comparison of failure risk values of remote office service design touch point of $\mathrm{Y}$ company

\begin{tabular}{llllr}
\hline Code & Traditional failure analysis value and ranking & & \multicolumn{2}{l}{$\begin{array}{l}\text { Failure analysis value and ranking based on } \\
\text { triangular fuzzy number }\end{array}$} \\
\cline { 5 - 6 } \cline { 5 - 5 } & Risk priority number & Failure risk ranking & $\begin{array}{l}\text { Failure risk priority } \\
\text { number FRPN }\end{array}$ & Failure risk ranking \\
\hline F1 & 100.4063 & 8 & 352.148 & 2 \\
F2 & 79.6875 & 9 & 142.223 & 7 \\
F3 & 112.8125 & 7 & 244.802 & 4 \\
F4 & 149.625 & 6 & 249.217 & 3 \\
F5 & 235.4063 & 3 & 368.01 & 1 \\
F6 & 79.6875 & 9 & 184.005 & 5 \\
F7 & 192.5 & 5 & 130.434 & 10 \\
F8 & 244.6875 & 1 & 131.67 & 9 \\
F9 & 244.375 & 2 & 134.46 & 12 \\
F10 & 33 & 12 & 57.0625 & 11 \\
F11 & 60 & 11 & 72.0248 & 6 \\
F12 & 230.5625 & 4 & 179.284 &
\end{tabular}


Table 11 Comparative analysis of traditional failure risk values and failure risk values based on triangle fuzzy number

\begin{tabular}{lll}
\hline Project & $\begin{array}{l}\text { Risk priority } \\
\text { number RPN based } \\
\text { on traditional } \\
\text { failure analysis }\end{array}$ & $\begin{array}{l}\text { Failure risk priority } \\
\text { number FRPN } \\
\text { based on triangular } \\
\text { fuzzy number }\end{array}$ \\
\hline $\begin{array}{l}\text { Number of service } \\
\text { design touch } \\
\text { points }\end{array}$ & 12 & 12 \\
$\begin{array}{l}\text { Maximum number } \\
\text { of repetitions of } \\
\text { risk value }\end{array}$ & 2 & 0 \\
$\begin{array}{l}\text { Repetition rate of } \\
\text { risk value }\end{array}$ & $1 / 6$ & 0 \\
\hline
\end{tabular}

and support. Through the fuzzy failure mode effect analysis of the failure of the service design touch point in the whole service process, the failure mode and effect analysis are carried out to determine the priority of service design touch point redesign (see Table 9, and the service design touch point with high failure risk are designed in combination with service design thinking. (The service design plan is shown in Fig. 6b).

From Fig. 6 we can draw a more targeted design service blueprint after using this method to analyze the failure of service design touch point. Compared with the traditional method, the background program is added to provide services to remote employees at the time of the service design touch point with greater failure risk.

\subsection{Case analysis}

In order to verify the effectiveness of this method, four experts were involved in the failure analysis of 12 online office service design touch points of Y company by the traditional FMEA method. After the failure analysis task is completed, calculate the traditional failure risk priority number (RPN), and sort the failure risks according to the RPN, as shown in Table 10.

Columns 2 and 3 of Table 10 are the service design touch point failure risk values output by the traditional FMEA analysis, and columns 4 and 5 of Table 10 are the service design touch point fuzzy failure risk numbers output by the FMEA analysis based on the improved triangular fuzzy number. According to Table 10, the number of service design touch points and the number of duplicates of the target object are analyzed, as shown in Table 11.

It can be concluded from Table 11 that the repetition rate of FRPN value for the risk value of service design touch point failure analysis is low by using fuzzy triangle, which ensures that the priority touch point of service design will not be ignored in the design process due to the low RPN value to some extent. Compared with the failure risk value RPN value obtained from traditional FMEA analysis, it is more targeted to guide the service design touch point remodeling design. It can also be seen from the design service blueprint in Fig. 6 that the background support system of the service blueprint designed by the designer according to the risk assessment results proposed in this paper is more perfect. Using the failure analysis method based on fuzzy triangle number to analyze the failure risk value of the service design touch point can better guide the remodeling design of the service design touch point to a certain extent.

\section{Conclusion}

In this study, the service design touch point failure modes are designed for remote collaborative office services. Using the fuzzy failure mode and impact analysis theory, the risk priority value of each service design touch point failure mode is determined, and the service design touch point failure modes are sorted according to the risk priority. Compared with the previous expert weight assignment, the weight assignment matrix of different types of experts is determined according to the attribute differences of experts, which makes the results of the three elements of failure mode and risk priority value more scientific and reasonable. Through the ranking of risk priority value, the redesign of service design touch point of enterprises is more targeted and precise to reduce the cost in the process of remote collaborative office. It is worth to note that the proposed method is still feasible despite some deficiencies.

In the future, we will introduce more appropriate methods to analyze and study the dynamic changes of corporate remote office services in order to meet the needs of remote office models and provide effective assistance to enterprises.

Funding The author(s) disclosed receipt of the following financial support for the research, authorship, and/or publication of this article: The authors would like to thank the subjects for their participation in the experimental study. This research was supported by Shaanxi Province Innovation Capability Support Program Funded Project (2021PT-025) and Shaanxi "Outstanding Youth" Talent Support Project for Universities (2020-50) and Humanities and Social Sciences Research Plan Project of Shaanxi Provincial Department of Education (Project No. 21JK0070).

\section{Declarations}

Conflict of interest All authors declare that they have no conflict of interest. 


\section{References}

1. Deng, M., Gu, X.: Information acquisition, emotion experience and behaviour intention during online shopping: an eye-tracking study. Behav. Inf. Technol. 40(7), 635-645 (2021)

2. Jeffrey Hill, E., Grzywacz, J.G., Allen, S., Blanchard, V.L., MatzCosta, C., Shulkin, S., Pitt-Catsouphes, M.: Defining and conceptualizing workplace flexibility. Commun. Work Family 11(2), 149-163 (2008)

3. Sivakumar, S.C., Robertson. W.: Development of an effective remote interactive laboratory for online internetworking education. In: Hawaii International Conference on System Sciences (2004)

4. Rosenboom, O., Walter, C., Rizkalla, S.: Strengthening of prestressed concrete girders with composites: Installation, design and inspection. Constr. Build. Mater. 23(4), 1495-1507 (2009)

5. Abdullah, T.A., Wahab, D.A., Lashlem, A.A.: An overview use of analytic hierarchy process (AHP) in design for remanufacturing activities. In: The International Symposium on the Analytic Hierarchy Process (2013)

6. Wisniewski, M.J.M.S.: Using SERVQUAL to assess customer satisfaction with public sector services. Manag. Serv. Quality An Int. J. 11(6), 380-388 (2001)

7. Kutlu, A.C., Ekmekçioğlu, M.: Fuzzy failure modes and effects analysis by using fuzzy TOPSIS-based fuzzy AHP. Expert Syst. Appl. 39(1), 61-67 (2012)

8. Berti, P., Dujany, M., Marana, M., Viérin, E., Barbagelata, A.R.: FMEA in transfusion risk management: experience in a hospital-based transfusion service. In: XIX Regional Congress of the International Society of Blood Transfusion (ISBT), Eastern Mediterranean and Europe (2009)

9. Li, X., Ran, Y., Zhang, G., He, Y.: A failure mode and risk assessment method based on cloud model. J. Intell. Manuf. 31(6), 1339-1352 (2020)

10. Ershadi, M.J., Maman, E.A., Maman, E.A.: A framework to enhance the procurement processes based on hybrid approach of FMEA-DEA. Int. J. Bus. Perform. Supply Chain Model. 11(2), 152-175 (2020)

11. Chuang, P.T.: Combining service blueprint and FMEA for service design. Serv. Ind. J. 27(2), 91-104 (2007)

12. Thornton, C., O'Flaherty, B.: Improving Customer Centric Design for Self-service Predictive Analytics. Springer, Berlin (2015)

13. Chen, S.H.: Determining the service demands of an aging population by integrating QFD and FMEA method. Qual. Quantity 50(1), 283-298 (2016)

14. Canepa, P., De Leo, C., Casciano, I., Rizzo, C., Sozzi, F., Ambrosini, F., Scaruffi, P.: Failure modes and effects analysis for testicular sperm extraction management process. Andrologia 52(3), e13506 (2020)

15. Wang, F.: Preference degree of triangular fuzzy numbers and its application to multi-attribute group decision making. Expert Syst. Appl. 178, 114982 (2021)

16. Hou, X., Yin, C., Li, Q.J.S.: Evaluation method of engineering quality coupling effect based on triangular fuzzy number (2019)

17. Yang, K., Zhang, L.: Research on credit risk evaluation of online supply chain finance with triangular fuzzy information. J. Intell. Fuzzy Syst. 37(2), 1921-1928 (2019)

18. Abdel-Basset, M., Mohamed, M., Hussien, A.N., Sangaiah, A.K.: A novel group decision-making model based on triangular neutrosophic numbers. Soft Comput. 22(20), 6629-6643 (2018)

19. Liu, Y., Fan, Z.P., Zhang, Y.: Risk decision analysis in emergency response: a method based on cumulative prospect theory. Comput. Oper. Res. 42, 75-82 (2014)

20. Lei, L.: Success factors of biotechnology industry based on triangular fuzzy number. Asian Agric. Res. 5, 17-21 (2013)
21. Toney, D., Pentella, M., Blank, E., Becker, S.: Creating a blueprint for the future: lessons learned from public health laboratories in the COVID-19 response. J. Public Health Manag. Pract. 27(1), S101-S105 (2021)

22. Case ANor, K., Teoh, P.C.: A diagnostic service tool using FMEA. Int. J. Comput. Integr. Manuf. 23(7), 640-654 (2010)

23. Qi, L., Yuan, S., Li, W.: Analysis on the relationships of stakeholders in service design. In: 2014 International conference on service sciences (ICSS) (2014)

24. Lee, C.H., Wang, Y.H., Trappey, A.J.: Service design for intelligent parking based on theory of inventive problem solving and service blueprint. Adv. Eng. Inform. 29(3), 295-306 (2015)

25. Wang, W.P.: A fuzzy linguistic computing approach to supplier evaluation. Appl. Math. Model. 34(10), 3130-3141 (2010)

26. Arabian-Hoseynabadi, H., Oraee, H., Tavner, P.J.: Failure modes and effects analysis (FMEA) for wind turbines. Int. J. Electr. Power Energy Syst. 32(7), 817-824 (2010)

27. Chiozza, M.L., Ponzetti, C.: FMEA: a model for reducing medical errors. Clin. Chim. Acta 404(1), 75-78 (2009)

28. Garcia, P.A., Schirru, R.: A fuzzy data envelopment analysis approach for FMEA. Progr. Nucl. Energy 46(3-4), 359-373 (2005)

29. Feili, H.R., Akar, N., Lotfizadeh, H., Bairampour, M., Nasiri, S.: Risk analysis of geothermal power plants using failure modes and effects analysis (FMEA) technique. Energy Convers. Manag. 72, 69-76 (2013)

30. Kirkire, M.S., Rane, S.B., Jadhav, J.R.: Risk management in medical product development process using traditional FMEA and fuzzy linguistic approach: a case study. J. Ind. Eng. Int. 11(4), 595-611 (2015)

31. Baehr, A., Oertel, M., Kröger, K., Eich, H.T., Haverkamp, U.: Implementing a new scale for failure mode and effects analysis (FMEA) for risk analysis in a radiation oncology department. Strahlenther. Onkol. 196(12), 1128-1134 (2020)

32. Akbari, R., Dabbagh, R., Ghoushchi, S.J.: HSE risk prioritization of molybdenum operation process using extended FMEA approach based on Fuzzy BWM and Z-WASPAS. J. Intell. Fuzzy Syst. 38(4), 5157-5173 (2020)

33. Jian-Xing, Y.U., Zhou, Q.J., Zun-Feng, D.U., Shao, Z.W., Feng, J.G.: Asset management for RCM-based offshore oil and gas production facilities. J. Tianjin Univ. Sci. Technol. 45(1), 36-42 (2012)

34. Fang, R., Wu, M., Jiang, S.: On-line status assessment of wind turbines based on improved fuzzy comprehensive evaluation method. J. Intell. Fuzzy Syst. 31(6), 2813-2819 (2016)

35. Han, L., Song, Y., Duan, L., Yuan, P.: Risk assessment methodology for Shenyang Chemical Industrial Park based on fuzzy comprehensive evaluation. Environ. Earth Sci. 73(9), 5185-5192 (2015)

36. Heid MJJMB (2008) Servicer-led solutions provide blueprint in rebuilding. U.S. Mortgage Market

37. Li, Y., Zhang, N., Siponen, M.: Keeping secure to the end: a longterm perspective to understand employees' consequence-delayed information security violation. Behav. Inform. Technol. 38(5), 435-453 (2019)

38. Barbieri, S., Fragniere, E., Sitten, M.S., Zambrano, G.: Proposal of a methodology to integrate the human factor in the service blueprint. J. Adv. Manag. Sci. 1(2), 207-2013 (2013)

Publisher's Note Springer Nature remains neutral with regard to jurisdictional claims in published maps and institutional affiliations. 